\title{
Orofaciodigital syndrome type II (Mohr syndrome): a case report
}

\author{
Bita Malekianzadeh ${ }^{1}$ (D) Fardis Vosoughi ${ }^{2}$ and Ramin Zargarbashi $i^{3,4^{*}}$
}

\begin{abstract}
Background: Orofacial digital syndrome is a rare genetic disorder with oral cavity, facial and digits anomalies. Orofacial digital syndrome type II, also called the "Mohr syndrome" is a very rare subtype that has been reported scarcely in Asia especially in Japanese patients.

Case presentation: The case is an Iranian 5-year old girl who had been admitted for orthopedic surgery. She surprisingly had pre and postaxial polydactyly of all the four limbs concurrent with syndromic face and most of the features of Orofaciodigital syndrome type II.

Conclusion: Mohr syndrome, anesthesia and surgical considerations are discussed in this case report. It is recommended to consider these considerations and the possibility of OFDS in every child with pre and postaxial polydactyly of the four limbs and to try to distinguish type II from other types of ODFS.
\end{abstract}

Keywords: Orofaciodigital syndrome, Mohr syndrome, Polydactyly, Central incisors

\section{Background}

Polydactyly is a relatively common upper limb anomaly compared to other musculoskeletal congenital anomalies $[1,2]$. Concurrent pre and postaxial polydactyly of multiple limbs with concomitant facial anomalies, on the other hand, is not so common. A child with multiple limb polydactyly and abnormal facial features should further be assessed to look for oral anomalies with suspicion of OFDS. Orofacial digital syndrome (OFDS) is a rare congenital disorder characterized by a range of clinical anomalies, such as malformations of the oral cavity including mouth, tongue, and teeth as well as developmental disorder of the face, head, nose, eyes, fingers, and toes. Most of these features are present at birth. Currently, at least 13 clinical types of OFDS have been identified which could be classified

\footnotetext{
* Correspondence: ramin.zargarbashi@gmail.com;

raminzargar.ortho@gmail.com

${ }^{3}$ Department of Pediatric Orthopedy, Faculty of Medicine, Tehran University of Medical Sciences, Tehran, Iran

${ }^{4}$ Children's Medical Center, Tehran University of Medical Sciences, Tehran, Iran

Full list of author information is available at the end of the article
}

according to the existing anomalies [3-5]. Most of such children are born out of consanguineous marriages. OFDS can be inherited in form of autosomal dominant, autosomal recessive, $\mathrm{X}$-linked recessive, or $\mathrm{X}$-linked dominant. OFDS often has a recessive pattern, where both parents are mutation gene carriers. OFDS type I (Papillon-League and Psaume syndrome) is the most common type of OFDS with X-linked inheritance mode. The responsible gene for OFDS I could be diagnosed and confirmed through the genetic test. However, currently, there is no specific test for identifying the other types of OFDS. OFDS patients need medical care and some surgeries such as the reconstruction of cleft palate and limb deformities. OFDS type II or "Mohr syndrome" is a very rare disorder with an incidence of $1 / 1000000$ worldwide. It was first described as a familial disease in 1941 by Mohr. OFDS type II is an autosomal recessive syndrome and the responsible gene has not been fully specified. Diagnosis is based on the clinical picture which has been rarely reported in Asian countries [6-9]. In this study, a five-year-old Iranian

(c) The Author(s). 2020 Open Access This article is licensed under a Creative Commons Attribution 4.0 International License, which permits use, sharing, adaptation, distribution and reproduction in any medium or format, as long as you give appropriate credit to the original author(s) and the source, provide a link to the Creative Commons licence, and indicate if changes were made. The images or other third party material in this article are included in the article's Creative Commons licence, unless indicated otherwise in a credit line to the material. If material is not included in the article's Creative Commons licence and your intended use is not permitted by statutory regulation or exceeds the permitted use, you will need to obtain permission directly from the copyright holder. To view a copy of this licence, visit http://creativecommons.org/licenses/by/4.0/. The Creative Commons Public Domain Dedication waiver (http://creativecommons.org/publicdomain/zero/1.0/) applies to the data made available in this article, unless otherwise stated in a credit line to the data. 
girl with Mohr syndrome who was admitted for orthopedic surgery is reported.

\section{Case presentation}

A five-year-old girl was admitted to a tertiary pediatric center in Tehran, Iran for the reconstruction of foot deformity. The child was born of consanguineous parents and full term at birth. Her parents seemed healthy with no prior medical history. She had undergone uncomplicated anesthesia for orthopedic hand surgery and lingual frenectomy three times. Her development had been delayed. Her mother mentioned that she suffered from obstructive sleep apnea. Lab data including Complete Blood Cell Count with leukocyte differentials, Blood Urea Nitrogen, Creatinine, PT, PTT, and INR levels were all within normal limits. Echocardiography showed no cardiac anomaly. She presented with typical features of OFDS type II (Fig. 1), which included mouth cavity and facial deformities, tongue nodules, missing central incisors, high arch palate, broad nose, midline lip cleft, hypertelorism, as well as low-set ears (Fig. 2), and limb deformities. Bilateral polydactyly of hands (Fig. 3) that was corrected in previous surgeries and bilateral pre and postaxial polydactyly of feet (Fig. 4) were among her list of anomalies. She was scheduled for surgery to correct the foot deformity (Fig. 5). After performing electrocardiography, pulse oximetry, and noninvasive monitoring of blood pressure, lidocaine 1.5 $\mathrm{mg} / \mathrm{kg}$ and fentanyl $1 \mu \mathrm{g} / \mathrm{kg}$ were injected. Anesthesia induction was performed with propofol $2 \mathrm{mg} / \mathrm{kg}$ without any muscle relaxants. Direct laryngoscopy with Miller blade was done and uncuffed endotracheal tube was inserted. Laryngoscopic grade was II and dorsal port of vocal cords and bifida uvula were observed. Mirror foot deformity of right foot was corrected through a 94-min surgery. During the operation, the surgeon excised pre and postaxial rays in order to create a suitable foot for wearing shoes. Serial casting after the surgery was performed in order to stretch soft tissue contractures. At the end of surgery, the patient was extubated and after recovery, she was transferred to the surgical ward. She was stable without experiencing any complications during the anesthesia and recovery time.

\section{Discussion and conclusions}

OFDS includes a wide variety of symptoms which make the diagnosis confusing for the pediatric orthopedic surgeon. The incidence of OFDS type I, the most common type of this syndrome, is $1 / 50000-1 / 250000$ live birth. Mutation of chromosome X (22.3-22.2) is responsible for this disorder. This gene (Xp22) plays an important role in the development of body organs such as brain, face, limbs, and kidneys [10-12]. It encodes a protein localized in the centrosome and basal body of primary
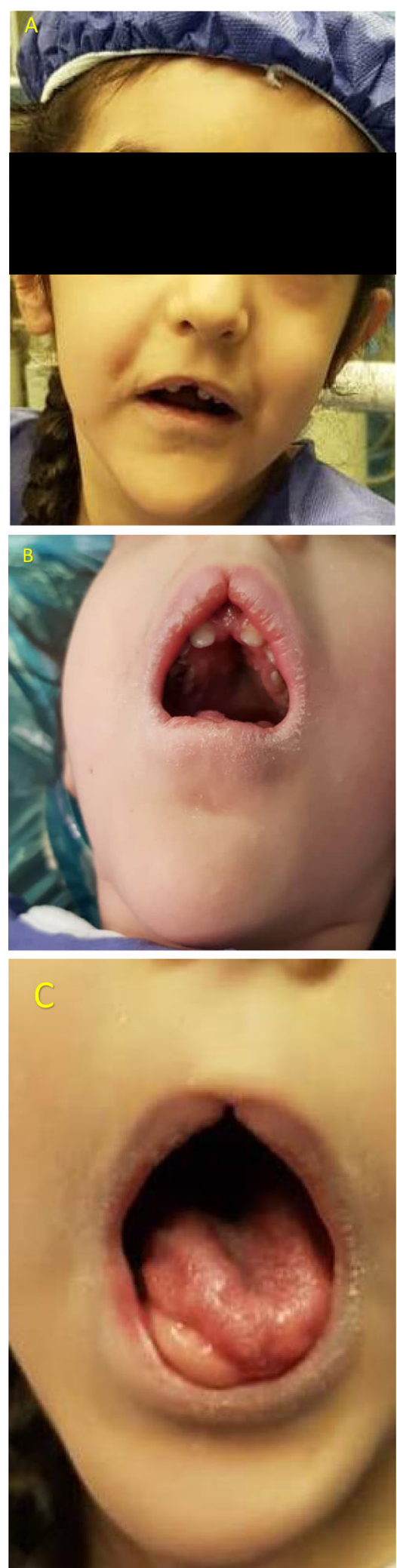

Fig. 1 Orofacial manifestations of Mohr syndrome including the patient's face (a), midline lip cleft (b), high-arch palate (b), absence of central incisors (b) and presence of tongue nodule (c) 


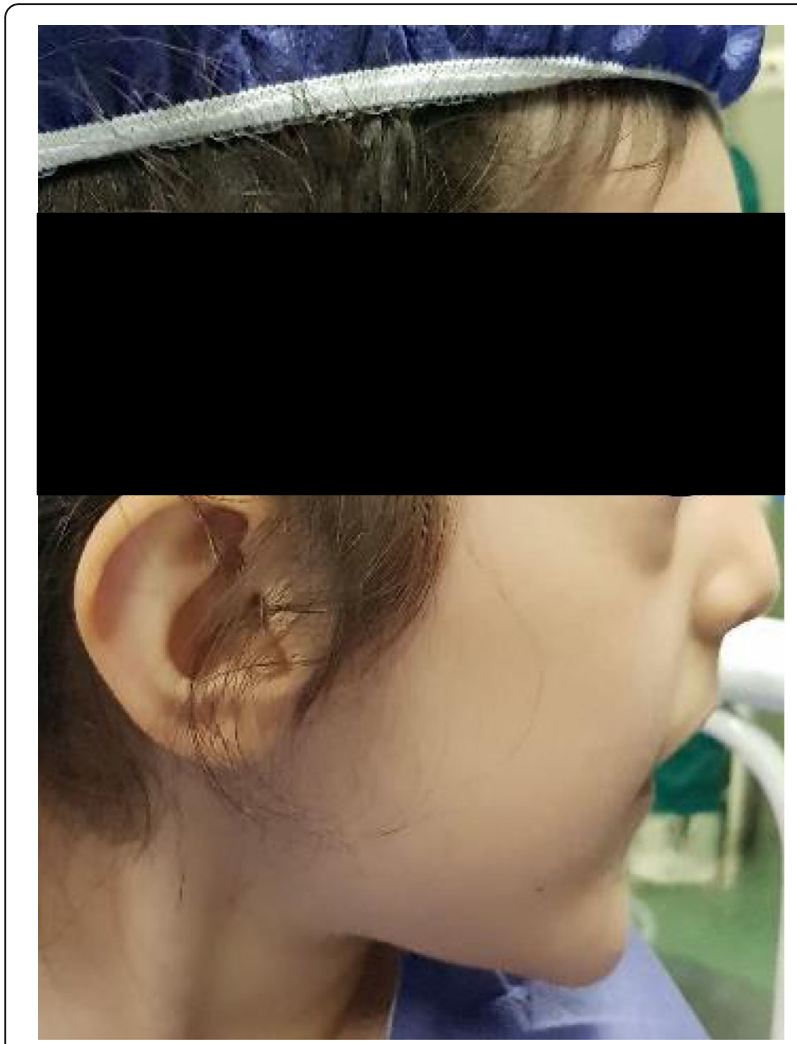

Fig. 2 Low-set ear
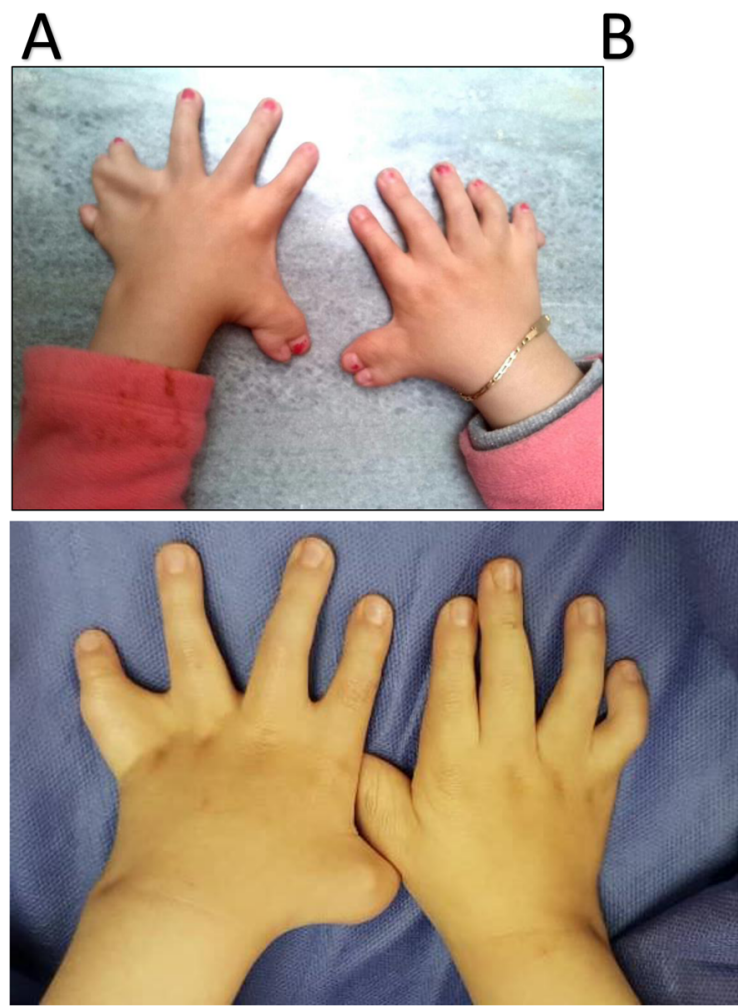

Fig. 3 Pre and postaxial polydactyly of hands, before (a) and several years after (b) surgical correction

OFDS is also important due to associated involvement of heart, kidney, and central nervous system, especially in type $1[11,16,17]$. In our case, these organs were not involved. Craniofacial anomaly and high arch palate in Mohr syndrome can be challenging for anesthesiologists. Difficulty in airway should be anticipated and discussed with the anesthesiologist beforehand. High-arch palate which is associated with some congenital syndromes, is a known cause of difficult laryngoscopy. It may also be difficult to place supraglottic devices such as laryngeal mask airway in these patients, so difficult airway equipment availability is recommended. However, in most of the reported cases, intubation was performed by an anesthesiologist without the use of these devices [18, 19]. Using a Miller blade, the Mallampati grade of our patient was 2 and head extension was normal. Mask ventilation was adequate and we did not encounter any difficulty during intubation.

Mohr syndrome is a very rare type of OFDS. Patients often need several surgical interventions from infancy to adulthood and the surgical team should be prepared for a difficult intubation. Video-assisted laryngoscopy might be safer in these patients.

Polydactyly of the 4 limbs (tetra polydactyly) is very rare, and so is simultaneous preaxial and postaxial polydactyly. We performed an extensive literature search in contrast to type II. Distinguishing different types of 

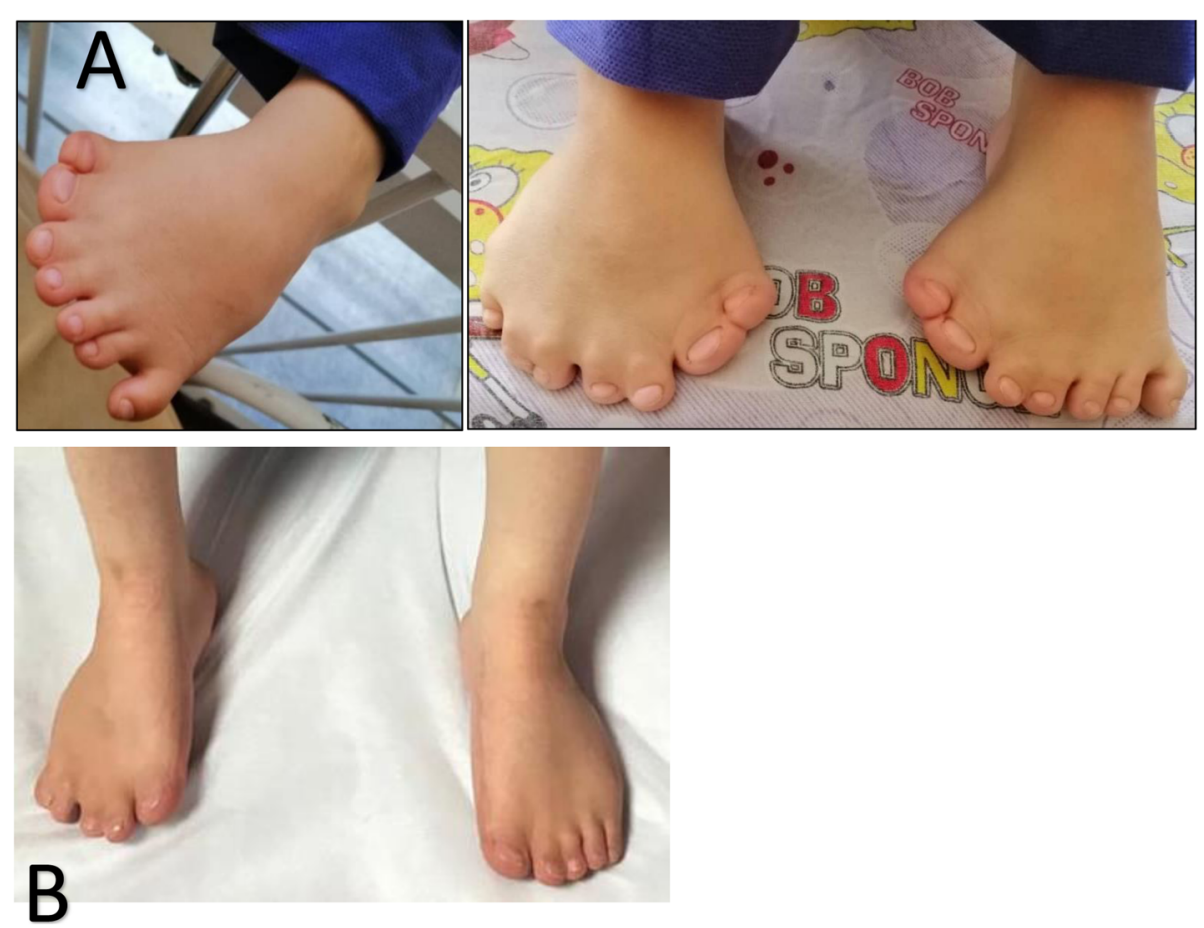

Fig. 4 preaxial and postaxial polydactyly (mirror deformity) of the feet before (a) and one year after surgical correction (b) years old
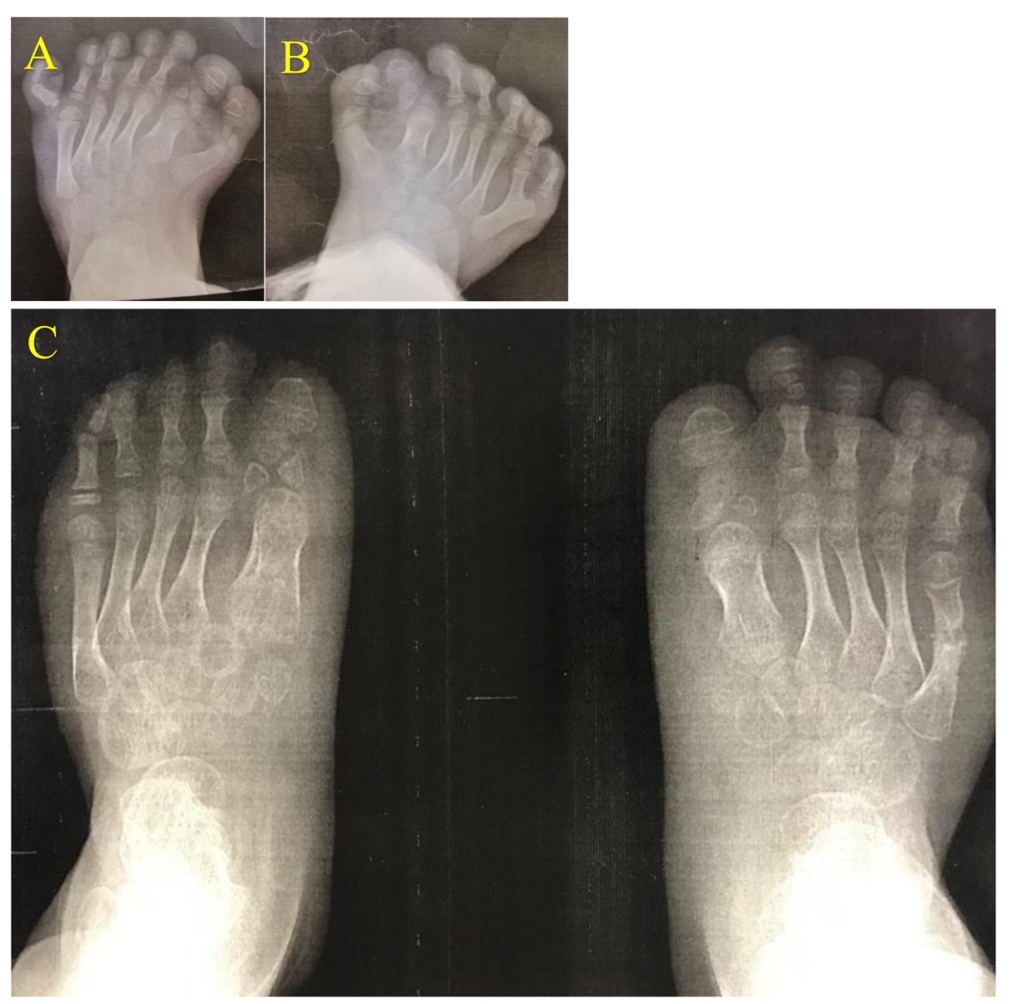

Fig. 5 left (a) and right (b) foot anteroposterior radiographs of the patient showing bilateral polydactyly before and after (c) surgery 
and the only known associated entities were Ellis van Kreveld and OFD syndromes. Hence it is recommended to consider the possibility of OFDS in every child with pre and postaxial tetra polydactyly and then evaluate for associated brain, cardiac and maxillofacial anomalies and be prepared for a difficult intubation in these patients.

\section{Abbreviations}

OFDS: Orofacial digital syndrome; PT: Prothrombin Time; PTT: Partial thromboplastin Time; INR: International Normalized Ratio

\section{Acknowledgements}

None.

\section{Authors' contributions}

RZ developed the conception and design of the study and contributed to manuscript writing. FV contributed to the manuscript preparation and final review of the manuscript. BM contributed to the data gathering and design of the study and manuscript writing. All authors read and approved the final manuscript.

\section{Funding}

No funding was received for the current study.

\section{Availability of data and materials}

Not Applicable.

Ethics approval and consent to participate

The case was reviewed and confirmed by the Institutional Review Board. Consent to participate

$\mathrm{N} / \mathrm{A}$ (this is not an interventional study).

\section{Consent for publication}

Written informed consent was obtained from the patient's legal guardian(s) for publication of this case report and any accompanying images. A copy of the written consent is available for review by the Editor-in-Chief of this journal.

\section{Competing interests}

All authors declare that there were no competing interests for this study.

\section{Author details}

${ }^{1}$ Anesthesiology Department, Tehran University of Medical Sciences, Tehran, Iran. ${ }^{2}$ Department of Orthopaedic and Trauma Surgery, Shariati Hospital and School of Medicine, Tehran University of Medical Sciences, Tehran, Iran.

${ }^{3}$ Department of Pediatric Orthopedy, Faculty of Medicine, Tehran University of Medical Sciences, Tehran, Iran. ${ }^{4}$ Children's Medical Center, Tehran

University of Medical Sciences, Tehran, Iran.

Received: 17 June 2020 Accepted: 23 November 2020

Published online: 30 November 2020

\section{References}

1. Mano H, Fujiwara S, Takamura K, Kitoh H, Takayama S, Ogata T, et al. Congenital limb deficiency in Japan: a cross-sectional nationwide survey on its epidemiology. BMC Musculoskelet Disord. 2018;19(1):262

2. Vasluian E, van der Sluis CK, van Essen AJ, Bergman JEH, Dijkstra PU, Reinders-Messelink HA, et al. Birth prevalence for congenital limb defects in the northern Netherlands: a 30-year population-based study. BMC Musculoskelet Disord. 2013;14(1):323.

3. Gurrieri F, Franco B, Toriello H, Neri G. Oral-facial-digital syndromes: review and diagnostic guidelines. Am J Med Genet A. 2007;143A:3314-23.

4. Abuhamda AF, Elsous A. Oral-Facial-Digital Syndrome Type II (Mohr Syndrome) in Palestine. Ann Clin Lab Res. 2018;6(4);259.

5. Adyanthaya A, Adyanthaya S. Oral-facial-digital syndrome type 1: a review. Bangladesh J Med Sci. 2015;14:130.

6. Padmini P, Narasinga Rao B. oro-facial digital syndrome. Int J Curr Res. 2017; 9:47293-5.

7. Diz Dios P, Alvarez-Iglesias V, Feijoo J, Limeres J, Leston J, Tomás Carmona I, et al. A novel mutation in the OFD1 (CXorf5) gene may contribute to oral phenotype in patients with oral-facial-digital syndrome type 1. Oral Dis. 2011;17:610-4.

8. Tezerjani M. A novel mutation in the OFD1 gene in a family with Oral-facialdigital syndrome type 1. Iran J Public Health. 2016:45:1359-66.

9. Havle A, Shedge S, Malashetti S, Jain V. Oro-facial-digital syndrome type II with otolaryngological manifestations. J Oral Maxillofac Pathol. 2015;19(2): 266.

10. Kirzioğlu Z, Öz E. Oral-facial-digital syndrome type 1:Oral findings in a 6year-old girl; 2018

11. Kathariya R, Asnani K, Bansal A, Jain H, Devanoorkar A, Shah NK. Distinction of Mohr's syndrome from OFD type I: case report and review of the literature. Oral Health Dent Manag. 2013;12(3):180-5.

12. Thauvin-Robinet C, Cossée M, Cormier-Daire V, Van Maldergem L, Toutain A, Alembik Y, et al. Clinical, molecular, and genotype-phenotype correlation studies from 25 cases of oral-facial-digital syndrome type 1: a French and Belgian collaborative study. J Med Genet. 2006;43(1):54-61.

13. Bruel A-L, Franco B, Duffourd $Y$, Thevenon J, Jego L, Lopez E, et al. Fifteen years of research on oral-facial-digital syndromes: from 1 to 16 causal genes. J Med Genet. 2017;54(6):371.

14. Ferrante M, Giorgio G, Feather S, Bulfone A, Wright V, Ghiani M, et al. Identification of the gene for Oral-facial-digital type I syndrome. Am J Hum Genet. 2001:68:569-76.

15. Shawky R, Elsayed S, Abd-Elkhalek H, Gad S. Oral-facial-digital syndrome type II: transitional type between Mohr and Varadi. Egypt J Med Hum Genetics. 2013;14:311-5.

16. Dua H, Edbor A, Asudani B. Orocfacial digital syndrome type II -- Mohr's syndrome. J Indian Med Assoc. 2013;111(4):268-9 271.

17. Azukizawa T, Yamamoto M, Narumiya S, Takano T. Oral-facial-digital syndrome type 1 with hypothalamic hamartoma and Dandy-Walker malformation. Pediatr Neurol. 2013;48(4):329-32.

18. Bala R, Hazarika A, Pandia MP, Kumar N. High arch palate: a bane for ProSeal laryngeal mask airway but a boon for I-gel. J Anaesthesiol Clin Pharmacol. 2015:31(4):568.

19. Tsukamoto M, Hitosugi T, Yamanaka H, Yokoyama T. Bifid epiglottis, higharched palate, and mental disorder in a patient with Pallister-hall syndrome. Indian J Anaesth. 2018;62(10):825-7.

\section{Publisher's Note}

Springer Nature remains neutral with regard to jurisdictional claims in published maps and institutional affiliations.
Ready to submit your research? Choose BMC and benefit from:

- fast, convenient online submission

- thorough peer review by experienced researchers in your field

- rapid publication on acceptance

- support for research data, including large and complex data types

- gold Open Access which fosters wider collaboration and increased citations

- maximum visibility for your research: over $100 \mathrm{M}$ website views per year

At BMC, research is always in progress.

Learn more biomedcentral.com/submission 